\title{
ARTICLE
}

\section{North Carolina macular dystrophy: phenotypic variability and computational analysis of disease-implicated non-coding variants}

David J. Green ${ }^{1}$, Eva Lenassi ${ }^{1-3}$, Cerys S. Manning ${ }^{4}$, David McGaughey ${ }^{5}$, Vinod Sharma $^{3}$, Graeme C. Black ${ }^{1,2}$, Jamie M. Ellingford ${ }^{1}$, Panagiotis I. Sergouniotis ${ }^{1-3}$

${ }^{1}$ Division of Evolution and Genomic Sciences, School of Biological Sciences, Faculty of Biology, Medicines and Health, University of Manchester M13 9PT, UK.

${ }^{2}$ Manchester Centre for Genomic Medicine, St Mary's Hospital, Manchester University NHS Foundation Trust, Manchester M13 9WL, UK.

${ }^{3}$ Manchester Royal Eye Hospital, Manchester University NHS Foundation Trust, Manchester M13 9WL, UK.

${ }^{4}$ Division of Developmental Biology and Medicine, School of Medical Sciences, Faculty of Biology, Medicines and Health, University of Manchester M13 9PT, UK.

${ }^{5}$ Ophthalmic Genetics and Visual Function Branch, National Eye Institute, National Institutes of Health, Bethesda, Maryland, United States.

DJG and EL contributed equally to the work and should therefore be regarded as equivalent first authors

${ }^{*}$ Corresponding Author: Panagiotis I. Sergouniotis FRCOphth, PhD; Manchester Centre for Genomic Medicine, St Mary's Hospital, Oxford Road, Manchester M13 9WL, UK; email: panagiotis.sergouniotis@manchester.ac.uk.

Word count: 3,599 
Funding information: Christopher Green Doctoral Fellowship (DJG), UK National Institute for Health Research (NIHR) Clinical Lecturer Award (CL-2017-06-001, PIS), Health Education England Postdoctoral Research Fellowship (JME), Wellcome Trust Sir Henry Wellcome Fellowship (103986/Z/14/Z, CSM).

Commercial relationships disclosures: D.J. Green, None; E. Lenassi, None; C.S. Manning, None; D. McGaughey, None; V. Sharma, None; G.C. Black, None; J.M. Ellingford, None; P.I. Sergouniotis, None. 
medRxiv preprint doi: https://doi.org/10.1101/2021.03.05.21252975; this version posted March 8, 2021. The copyright holder for this preprint (which was not certified by peer review) is the author/funder, who has granted medRxiv a license to display the preprint in perpetuity.

It is made available under a CC-BY-NC-ND 4.0 International license .

\section{ABSTRACT}

Purpose: North Carolina macular dystrophy (NCMD) is an autosomal dominant, congenital disorder affecting the central retina. Here, we report clinical and genetic findings in three families segregating NCMD and use epigenomic datasets from human tissues to gain insights into the effect of NCMD-implicated variants.

Methods: Clinical assessment and genetic testing were performed. Publiclyavailable transcriptomic and epigenomic datasets were analyzed and the 'Activity-byContact' $(A B C)$ method for scoring enhancer elements and linking them to target genes was used.

Results: A previously-described, heterozygous, non-coding variant upstream of the PRDM13 gene was detected in all six affected study participants (chr6:100,040,987G>C [GRCh37/hg19]). Inter- and intra-familial variability were observed; the visual acuity ranged from 0.0 to 1.6 LogMAR and fundoscopic findings ranged from visually insignificant, confluent, drusen-like macular deposits to coloboma-like macular lesions. Variable degrees of peripheral retinal spots (which were easily detected on widefield retinal imaging) were observed in all study subjects. Notably, a 6-year-old patient developed choroidal neovascularization and required treatment with intravitreal bevacizumab injections. Computational analysis of the five single nucleotide variants that have been implicated in NCMD revealed that these non-coding changes lie within two putative enhancer elements; these elements are predicted to interact with $P R D M 13$ in the developing human retina. PRDM13 was found to be expressed in the fetal retina, with highest expression in the amacrine precursor cell population. 
medRxiv preprint doi: https://doi.org/10.1101/2021.03.05.21252975; this version posted March 8, 2021. The copyright holder for this preprint (which was not certified by peer review) is the author/funder, who has granted medRxiv a license to display the preprint in perpetuity. It is made available under a CC-BY-NC-ND 4.0 International license.

Conclusions: We provide further evidence supporting the role of $P R D M 13$

dysregulation in the pathogenesis of NCMD and highlight the utility of widefield retinal imaging in individuals suspected to have this condition. 
medRxiv preprint doi: https://doi.org/10.1101/2021.03.05.21252975; this version posted March 8, 2021. The copyright holder for this preprint (which was not certified by peer review) is the author/funder, who has granted medRxiv a license to display the preprint in perpetuity.

It is made available under a CC-BY-NC-ND 4.0 International license .

\section{INTRODUCTION}

North Carolina macular dystrophy (NCMD) is a developmental abnormality affecting the macula, the central part of the retina that is responsible for detailed vision. NCMD is present at birth and rarely progresses. It is inherited as an autosomal dominant trait and although it is thought to be completely penetrant, it exhibits significant intra- and inter-familial variability. The phenotype ranges from visually inconsequential subtle retinal spots to macular coloboma-like lesions associated with significant visual impairment. ${ }^{1-6}$

NCMD was first described in the 1970s in a large pedigree of more than 500 individuals spanning seven generations. This kindred represented a portion of the descendants of two brothers who emigrated from Ireland to the mountains of North Carolina in the early $19^{\text {th }}$ century. ${ }^{7,8}$ Since the first description of the disease, families have been reported in Europe, North America, Asia, and elsewhere in the world. ${ }^{9-13}$ NCMD is genetically heterogeneous but most individuals carry genetic variants in an intragenic region in chromosome 6 located approximately 13,000 base-pairs from the neighboring gene. At least five single nucleotide changes and three copy number variants in this region have been associated with NCMD. ${ }^{1,3,4,9,14}$ These mutations alter DNA sequences that are likely to play a role in regulating the spatio-temporal expression of a retinal transcription factor PRDM13. PRDM13 is expressed in the fetal retina but is not found in adult tissues. ${ }^{1}$ Over-expression of this gene has been shown to affect retinal development in non-primate animal models. ${ }^{15-17}$ Intriguingly, changes near PRDM13 that have been associated with NCMD have also been implicated in a different condition, progressive bifocal chorioretinal atrophy (PBCRA). Although both these disorders affect the macula from birth, the latter is typically 
medRxiv preprint doi: https://doi.org/10.1101/2021.03.05.21252975; this version posted March 8, 2021. The copyright holder for this preprint

associated with disease progression and electrophysiological evidence of widespread retinal dysfunction. ${ }^{2}$ It is also noteworthy that a number of individuals with a phenotype indistinguishable from NCMD have been found to have copy number variants in a different locus in chromosome 5.,2

NCMD is part of an expanding group of Mendelian conditions caused by non-coding genetic variants that have an effect on gene expression (e.g., aniridia, ${ }^{18}$ limb malformations $\left.{ }^{19}\right)$. These variants often alter the sequence of regulatory elements, including transcriptional promoters and enhancers. Enhancers are short stretches of DNA, typically a few hundred base-pairs long, that bind transcription factors and enhance the expression of specific genes. ${ }^{20}$ There are hundreds of thousands of enhancers in the human genome but our understanding of their properties and repertoire is limited (e.g., where they reside, what genes they mediate their effects through, in which cells and in which specific time of development they act). Notably, our ability to detect and annotate enhancer elements is being transformed by emerging resources and tools such as the Encyclopedia of DNA Elements (ENCODE) 3 dataset, ${ }^{21}$ the Developmental Single Cell Atlas of Gene Regulation and Expression (DESCARTES), ${ }^{22,23}$ and the Activity-by-Contact (ABC) model. ${ }^{24}$ The ENCODE project consortium and the DESCARTES team have generated extensive functional genomic datasets across many cell and tissue contexts. Experiments conducted include assays aiming to identify enhancer elements such as DNase-seq (DNase I hypersensitive site sequencing), H3K27ac ChIP-seq (chromatin immunoprecipitation sequencing mapping H3K27 acetylation signals), and ATACseq (assay for transposase-accessible chromatin using sequencing), as well as assays studying the 3-dimensional architecture of the genome such as $\mathrm{Hi}-\mathrm{C}$ (all- 
medRxiv preprint doi: https://doi.org/10.1101/2021.03.05.21252975; this version posted March 8, 2021. The copyright holder for this preprint (which was not certified by peer review) is the author/funder, who has granted medRxiv a license to display the preprint in perpetuity.

It is made available under a CC-BY-NC-ND 4.0 International license .

versus-all chromosome conformation capture).${ }^{25} \mathrm{ABC}$ in contrast is a method that uses these epigenomic data to predict which enhancers regulate which genes. This model is based on the notion that an enhancer's effect on a gene depends on the enhancer's strength (estimated using chromatin accessibility data including ATACseq and H3K27ac ChiP-seq) weighted by how often it comes into 3-dimensional contact with the gene promoter (estimated using $\mathrm{Hi}-\mathrm{C}$ data). ${ }^{24}$ Although this method has been shown to be accurate, a limiting factor is the availability of tissue-specific chromatin accessibility datasets. Comprehensive tissue-specific $\mathrm{Hi}-\mathrm{C}$ data are also lacking but the developers of $\mathrm{ABC}$ expect that $\mathrm{Hi}-\mathrm{C}$ profiles averaged across a selection of cell types are adequate to map enhancer-gene connections. However, it remains possible that tissue- and context-specific data are required in some cases as the 3-dimensional conformation of the genome shows some plasticity during development. ${ }^{26}$ Although epigenomic datasets from various eye tissues are becoming increasingly available, ${ }^{27}$ there have been no systematic efforts to characterize enhancers that contribute to human vision.

In this report, we discuss phenotypic variability in individuals who have NCMD and are heterozygous for a specific non-coding variant, chr6:100,040,987G>C (GRCh37/hg19). We then utilize the ABC method and human transcriptomic and epigenomic datasets to gain mechanistic insights into the role of non-coding variation in NCMD. 
medRxiv preprint doi: https://doi.org/10.1101/2021.03.05.21252975; this version posted March 8, 2021. The copyright holder for this preprint (which was not certified by peer review) is the author/funder, who has granted medRxiv a license to display the preprint in perpetuity.

It is made available under a CC-BY-NC-ND 4.0 International license .

\section{METHODS}

\section{Participant ascertainment, phenotypic data collection \& clinical genetic testing}

Six individuals with a diagnosis of NCMD were retrospectively ascertained through the database of the North West Genomic Laboratory Hub, Manchester, UK. The study participants originated from three reportedly unrelated families who had European ancestries. The genetic and, to an extent, the clinical findings from two of the three affected individuals in one of these families have been previously reported. ${ }^{14}$ Ethics committee approval for the study was obtained from the North West Research Ethics Committee (11/NW/0421 and 15/YH/0365) and all investigations were conducted in accordance to the tenets of the Declaration of Helsinki.

All study participants were diagnosed with NCMD through the tertiary ophthalmic genetics service at Manchester University NHS Foundation Trust, Manchester, UK. Clinical assessment included visual acuity testing, dilated fundus examination, digital widefield fundus imaging, fundus autofluorescence (FAF) imaging, optical coherence tomography (OCT), and OCT-angiography (OCT-A). The Optos system (Optos PLC, Dunfermline, Scotland, UK) was used to obtain widefield images, the Topcon DRI OCT Triton device (Topcon GB, Newberry, Berkshire, UK) was used to obtain OCT and OCT-A scans, and the Spectralis system (Heidelberg Engineering, Heidelberg, Germany) was used to acquire FAF and OCT images in study participants.

Genetic testing was performed at the North West Genomic Laboratory Hub Diagnostic Laboratory, a UK Accreditation Service Clinical Pathology Accredited medical laboratory (Clinical Pathology Accredited identifier, no. 4015). DNA samples 
medRxiv preprint doi: https://doi.org/10.1101/2021.03.05.21252975; this version posted March 8, 2021. The copyright holder for this preprint (which was not certified by peer review) is the author/funder, who has granted medRxiv a license to display the preprint in perpetuity.

It is made available under a CC-BY-NC-ND 4.0 International license .

from all study subjects were screened using Sanger sequencing (BigDye v3.1) for the presence of known NCMD-implicated variants in chromosome 6 (upstream of the PRDM13 gene ${ }^{1}$ ). Two affected individuals also underwent genome sequencing as previously described (case $89794.1^{28}$ and case $75898.2^{14}$, see Figure 1 \& Table 1); the generated data were used for haplotype analysis (Supplementary Table 1).

\section{Analysis of variants implicated in North Carolina macular dystrophy}

To gain insights into the frequency of NCMD-implicated variants in the general population, we queried the Genome Aggregation Database (gnomAD; version 3.1) and the NHLBI Trans-Omics for Precision Medicine variant database (TOPMed; freeze 8). Neither of these cohorts is known to be enriched for patients with ophthalmic conditions. ${ }^{29,30}$

All variants known to be associated with NCMD (including the chr6:100,040,987G $>C$ change detected in the study participants) were assessed using in silico tools that attempt to predict the deleteriousness of non-coding sequence alterations. The following tools were utilized: CADD v1.6, ${ }^{31}$ nCER v2, ${ }^{32}$ and regBase v1.1. ${ }^{32}$ Positionspecific evolutionary constraint was evaluated using GERP (Genomic Evolutionary Rate Profiling) scores obtained through the UCSC (University of California, Santa Cruz) browser. ${ }^{33,34}$

To investigate the functional effects of the variants implicated in NCMD, we queried the $v 109$ release of the ENCODE portal for putative enhancer elements spanning the location of each variant; the SCREEN (Search Candidate cis-Regulatory Elements by ENCODE) v10 interface was used. ${ }^{21}$ We also inspected the eQTL catalogue and 
medRxiv preprint doi: https://doi.org/10.1101/2021.03.05.21252975; this version posted March 8, 2021. The copyright holder for this preprint (which was not certified by peer review) is the author/funder, who has granted medRxiv a license to display the preprint in perpetuity.

It is made available under a CC-BY-NC-ND 4.0 International license .

the GTEx (Genotype-Tissue Expression) and EyeGEx (Eye Genotype Expression) datasets for expression quantitative trait loci (eQTL) overlapping any of the detected elements (in addition to elements predicted in our subsequent analyses). ${ }^{35,36} \mathrm{We}$ then queried the DESCARTES chromatin accessibility database for the location of NCMD-implicated variants across all available tissues.

The $\mathrm{ABC}$ method for scoring enhancer elements and linking them to target genes was subsequently utilised. ${ }^{24}$ Raw ATAC-seq and H3K27ac ChIP-seq reads from macular and retinal tissue were obtained from a publicly-available dataset (GEO accession: GSE137311). ${ }^{27}$ The data were then processed using a consistent pipeline. The raw reads were trimmed for quality and adaptor content using the fastp tool with default quality control options. ${ }^{37}$ The trimmed ATAC-seq and ChIP-seq reads were aligned to the GRCh37/hg19 reference sequence using bowtie2 version 2.3.0 with the default parameters. ${ }^{38}$ The alignments were inspected in picard tools version 2.1 .0 (https://broadinstitute.github.io/picard/) and duplicate reads were removed. Only reads with a mapping quality $\geq 30$ were retained in subsequent analyses after filtration using the samtools "-view" command (version 1.9). ${ }^{39}$

The ABC method was then used to produce a set of potential enhancers using default parameters. As described in Fulco et al., initial peaks were obtained utilizing the MACS2 (Model-based Analysis of ChIP-Seq 2) peak caller on aligned ATAC-seq reads with a lenient $p$-value using the following options "-g hs, -p .1, --callsummits" ${ }^{40}$ The peaks were then extended by 250 base-pairs from their summits to produce a set of 500 base-pair "candidate regions"; overlapping regions were then merged. This resulted in a broad set of potential regulatory elements whose activity 
medRxiv preprint doi: https://doi.org/10.1101/2021.03.05.21252975; this version posted March 8, 2021. The copyright holder for this preprint (which was not certified by peer review) is the author/funder, who has granted medRxiv a license to display the preprint in perpetuity.

It is made available under a CC-BY-NC-ND 4.0 International license .

could be scored. To accomplish this, the ATAC-seq and H3K27ac ChIP-seq reads overlapping each candidate region were counted and averaged over biological replicates using the $\mathrm{ABC}$ "call neighborhoods" script. Finally, Hi-C data from human embryonic stem cells were downloaded from the juicebox archive at 5,000 base-pair resolution. ${ }^{26}$ Averaged Hi-C data provided by the ABC GitHub page were also used; these data were produced by averaging the Hi-C profiles from 10 cell types (GM12878, NHEK, HMEC, RPE1, THP1, IMR90, HUVEC, HCT116, K562, and KBM7). ABC scores were calculated by combining the estimated contact frequency (between the candidate region and the promoter of a gene) with the observed activity using the default parameters.

\section{Analysis of PRDM13 gene expression in the human retina}

To determine the expression level of PRDM13, we utilized a resource collecting human RNA-seq datasets: eyelntegration. ${ }^{41}$ All retinal tissue subtypes, RPE subtypes, and progenitor subtypes were queried. As eyelntegration does not contain data on macula, PRDM13 expression was also estimated from three macula RNAseq samples included in the GEO dataset GSE137311. ${ }^{27}$ In short, the raw reads were quantified using salmon ${ }^{42}$ (according to the same protocol used to build the eyelntegration dataset) and the value in TPM (transcripts per million) was calculated using tximport to merge reads to the gene level with the "lengthScaledTPM" option. The source code for this pipeline can be found at: www.githubdavemcg.com/EiaDBuild/. DESCARTES

(https://descartes.brotmanbaty.org/) was also queried for PRDM13 expression. Finally, PRDM13 expression was determined in individual cell types using the PLatform for Analysis of scEiad (plae v0.43) database (https://plae.nei.nih.gov/). 
medRxiv preprint doi: https://doi.org/10.1101/2021.03.05.21252975; this version posted March 8, 2021. The copyright holder for this preprint (which was not certified by peer review) is the author/funder, who has granted medRxiv a license to display the preprint in perpetuity.

It is made available under a CC-BY-NC-ND 4.0 International license .

\section{RESULTS}

\section{Clinical characteristics of study participants}

All six study participants were heterozygous for the chr6:100,040,987G>C variant.

This change has been previously detected in a number of families segregating $\operatorname{NCMD}^{1,3,4,14}$ and appeared to be on the same genetic background (haplotype) in at least two of the families included in this study (families 75898 and 89794;

Supplementary Table 1).

The age at presentation ranged from 3 to 46 years of age and the visual acuity ranged from 0.0 to 1.6 LogMAR. Three related patients presented in the first years of life and had vision of 0.5 LogMAR or worse, while the remaining three patients had normal vision and were only found to have drusen-like macular lesions on routine eye tests. The clinical findings are discussed in Table 1, the pedigrees are shown in Figure 1, and fundus imaging results are shown in Figures 2 and 3. The central macular changes resembled fine, confluent drusen; these lesions were hyperautofluorescent on FAF imaging and only partially corresponded to visible OCT changes. A notable finding in all participants was that of characteristic yellow-white drusen-like retinal lesions in the far periphery; these generally had a linear, radial configuration and could be detected on widefield imaging (Figure 3). The youngest study participant developed choroidal neovascularization in both maculae (diagnosed at 6 years of age). An active lesion was noted in the right eye on OCT-A and treatment with intravitreal bevacizumab injections was initiated. However, persistent subretinal fluid was present after four injections. 
medRxiv preprint doi: https://doi.org/10.1101/2021.03.05.21252975; this version posted March 8, 2021. The copyright holder for this preprint (which was not certified by peer review) is the author/funder, who has granted medRxiv a license to display the preprint in perpetuity.

It is made available under a CC-BY-NC-ND 4.0 International license .

\section{In silico analysis of variants associated with North Carolina macular dystrophy}

To date, five NCMD-implicated single nucleotide variants have been reported in the biomedical literature. These variants were found to be extremely rare upon inspection of large-scale genomic datasets (gnomAD and TOPMed; Table 2). Notably, the chr6:100,040,987G $>C$ change that was detected in the participants of this study was only identified in a single individual in gnomAD; this person was estimated to have European ancestry. None of the five NCMD-implicated variants was predicted to be deleterious by CADD. According to $\mathrm{nCER}$, the variants ranged from low to middle percentiles. ${ }^{43}$ The regBase Phred-like scores ranged from 5.7 to 19.8 on a Phred-like scale from 1 to 99 , with higher scores suggesting greater pathogenicity. Inspection of the UniPROBE (Universal PBM Resource for Oligonucleotide Binding Evaluation) database ${ }^{44}$ revealed that none of these diseasecausing variants is expected to significantly impact on a transcription factor binding site. The GERP scores ranged from -2.44 to 2.52 , suggesting variable evolutionary constraint (Table 2).

The degree to which NCMD-implicated variants map to putative enhancer elements was then investigated. Two such elements were found in the ENCODE dataset to span the locations of all five disease-associated variants (accessions:

EH37E1264999 and EH37E1265001I; DNase Z-scores: 3.81 and 1.70). We used the ABC method to assign these enhancers to target genes. Publicly-available chromatin accessibility (ATAC-seq and H3K27ac ChIP-seq) datasets from macula and retina were utilized. ${ }^{27}$ The Hi-C data recommended and provided by Fulco et al. ${ }^{24}$ were also used; these consist of a Hi-C profile that was averaged over a number of cell types. With this input, $A B C$ did not yield any predictions for the regions spanning the 
medRxiv preprint doi: https://doi.org/10.1101/2021.03.05.21252975; this version posted March 8, 2021. The copyright holder for this preprint (which was not certified by peer review) is the author/funder, who has granted medRxiv a license to display the preprint in perpetuity. It is made available under a CC-BY-NC-ND 4.0 International license .

location of NCMD-implicated variants. We then used the same ATAC-seq and H3K27ac ChIP-seq data but this time combined with Hi-C data from human embryonic stem cells. In macula, two predicted enhancers encompassed the locations of all five variants, and these regions were linked to the FLH5, SIM1, and PRDM13 genes.

As previous reports have associated $P R D M 13$ with $\mathrm{NCMD},{ }^{2,8}$ we then looked for enhancer elements predicted to be linked to PRDM13. Only elements that were within 100,000 base-pairs of the transcription initiation site were analyzed. This yielded a total of 53 candidate regions in macular tissue and 47 candidate regions in retinal tissue. To determine which of these candidates have the strongest regulatory effects on PRDM13, putative enhancers were ranked according to the overall $A B C$ score and to the individual components of this score (i.e. activity and contact) in isolation. The top 10 predicted elements ranked by their $A B C$ scores are shown in Supplementary Tables 2 and 3.

One previously reported NCMD-associated variant, chr6:100,046,783A $>C$, fell within a predicted enhancer that spanned approximately the same coordinates in both macula and retina (chr6:100,046,330-100,046,830 and chr6;100,046,348$100,046,848$, respectively) (Figure 4). In terms of ranking, this enhancer had low scores for activity but relatively high scores for $\mathrm{Hi}-\mathrm{C}$ contact when data from embryonic stem cells were used. Another four variants (chr6:100,040,906G>T, chr6:100,040,974A>C, chr6:100,040,987G>C, and chr6:100,041,040C>T) fell within a predicted enhancer spanning the chr6:100,040,653-100,041,153 region. This 
enhancer was found in macular tissue but not in retina, and also had low scores for activity but relatively high scores for $\mathrm{Hi}-\mathrm{C}$ contact.

Finally, we could not find any significant single-tissue eQTLs within any of the enhancer elements found in ENCODE or those predicted by the ABC method. Data from multiple tissues were inspected (including retinal samples included in EyeGEx).

\section{PRDM13 gene expression in the developing and adult human retina}

To gain insights into the cellular context in which the PRDM13 gene product exerts its function, we evaluated the levels of gene expression in a number of relevant tissues (Figure 5). The expression levels were significantly higher in the retina and macula than in the RPE, with the highest level found in fetal retinal tissue. Analysis of single-cell RNA-seq datasets revealed that PRDM13 is expressed in progenitor cells (including amacrine/horizontal precursors), with higher expression in the amacrine population. PRDM13 had low expression levels $(<0.2$ TPM) in all tissues found in the GTEx project dataset. For further detail on the expression of PRDM13 across tissues and cell types, please see Supplementary Table 4 and Supplementary Figure 1. 
medRxiv preprint doi: https://doi.org/10.1101/2021.03.05.21252975; this version posted March 8, 2021. The copyright holder for this preprint (which was not certified by peer review) is the author/funder, who has granted medRxiv a license to display the preprint in perpetuity.

It is made available under a CC-BY-NC-ND 4.0 International license .

\section{DISCUSSION}

In this study, we report clinical and genetic findings from six patients with NCMD. We highlight the utility of widefield retinal imaging in individuals suspected to have NCMD (Figure 3) and discuss the need for monitoring for choroidal neovascularization, particularly in young affected children. Furthermore, we perform computational analysis of NCMD-associated changes, with the results further supporting the role of PRDM13 dysregulation in the pathogenesis of the condition.

Phenotypic variability is incompletely understood but common in NCMD. ${ }^{1,3}$ Thus, it is not surprising that significant differences in clinical presentation were observed among the participants of this study. It is worth highlighting though that the three mildest cases were asymptomatic and were initially incorrectly diagnosed in adulthood as having a form of early-onset macular drusen; OCT imaging revealed that these macular changes were unlike typical drusen (Figure 2) and genetic testing highlighted the congenital nature of these lesions. It is noteworthy that histopathologic examination of an enucleated eye from a 72-year-old patient with a clinical diagnosis of NCMD revealed sub-RPE deposits. ${ }^{45}$ However, OCT findings from this and other studies ${ }^{9}$ suggest that at least a subset of these lesions are anterior to the RPE. The most severely affected participant in this study was a 6year-old male patient who had coloboma-like excavation and subretinal fibrosis in both maculae. Notably, he experienced moderate/severe visual loss due to the formation of choroidal neovascularization. This is a rare but sight-threatening complication of NCMD that can occur in both children and adults. ${ }^{1,5,46,47}$ A previous report has shown that intravitreal bevacizumab injections can improve vision and 
medRxiv preprint doi: https://doi.org/10.1101/2021.03.05.21252975; this version posted March 8, 2021. The copyright holder for this preprint (which was not certified by peer review) is the author/funder, who has granted medRxiv a license to display the preprint in perpetuity.

It is made available under a CC-BY-NC-ND 4.0 International license .

decrease intraretinal fluid. However, multiple injections (in a treat-and-extend protocol) may be required. ${ }^{46}$

We highlight an under-recognized fundoscopic finding of NCMD: multiple drusen-like spots in the peripheral retina. These were noted in all study participants and were easily detected on widefield retinal imaging (Figure 3). Although this feature is not pathognomonic, it prompted targeted genetic testing in one of the probands. Similar retinal abnormalities have been previously described in a number of affected families, including in the original NCMD kindred. $5,6,11,48,49$ These peripheral lesions should therefore be sought after in all individuals with a clinical presentation suggestive of NCMD and their presence should provide additional justification for requesting focused genetic screening. Further retinal imaging, including widefield OCT, is expected to provide important insights into the nature of this common but frequently overlooked feature of NCMD.

Although a number of non-coding genetic variants have been associated with NCMD, our understanding of the molecular pathology of this condition remains incomplete. The recent emergence of comprehensive functional genomic datasets from adult and fetal human tissue ${ }^{21,22,27}$ has enabled in-depth analysis of noncoding changes like the ones implicated in this disorder. We found that all NCMDcausing variants fall within enhancer elements that appear to be active during development and to be linked to the retinal transcription factor PRDM13. A number of observations relating to our in silico analysis are worthy of further discussion. First, the candidate enhancer that encompasses chr6:100,040,987G>C, the variant carried by the six study participants, was absent when retina-derived epigenomic data were 
used and was only highlighted when a dataset from macular tissue was utilized (Figure 4). Second, there were stark differences in the computational predictions of the $\mathrm{ABC}$ algorithm depending on the type of $\mathrm{Hi}-\mathrm{C}$ data used as input (averaged/nontissue-specific vs. embryonic tissue-specific profiles). This is notable as the developers of the $\mathrm{ABC}$ algorithm concluded that a Hi-C profile generated by averaging over several tissue types performed equally well to tissue-specific data. However, our findings indicate a potential pitfall in using averaged $\mathrm{Hi}-\mathrm{C}$ data for genes that are most highly expressed during development.

The human retina emerges in three main stages. The early retina is characterized by retinal progenitor proliferation and RPE emergence (5-7 post-conception week); this is followed by ganglion cell production and initiation of the programs that underlie the development of horizontal cells, amacrine cells, and cone photoreceptors (7-10 post-conception week). Subsequently, cone, amacrine, rod, bipolar, and Muller glia cells sequentially emerge (12-18 post-conception week). ${ }^{50,51}$ Interestingly, the morphological differentiation of the fovea is completed earlier than other regions for all cell types. ${ }^{50}$ Our gene expression analyses of human tissues revealed that PRDM13 is predominantly expressed in the retinal progenitor and the amacrine cell populations. Amacrine cells are the most diverse class of retinal neurons and are often subdivided based on the expression of inhibitory y-aminobutyric (GABA) or glycine. Studies in animal models have shown that PRDM13 is a key determinant of amacrine cell fate and promotes the generation of amacrine cell subtypes (with a bias towards a glycinergic phenotype). Given that duplications of the PRDM13 region are an established cause of NCMD, it has been proposed that over-expression of this gene during development is the main disease mechanism. ${ }^{15}$ This is supported 
by findings in Drosophila, Xenopus, and murine retinae, although none of these animal models have a macula. ${ }^{16,17}$ How impaired amacrine cell specification leads to macular abnormalities remains unclear. It is noteworthy though that the inner retinal layers (including the amacrine cell bodies) appeared normal on OCT imaging (Figure 2). Previous studies have however reported cases with subtle foveal hypoplasia ${ }^{3}$ or electrophysiological findings ${ }^{15}$ suggesting amacrine cell abnormalities. These are however sporadic reports and in-depth phenotyping of more affected individuals will provide further insights.

In conclusion, we have used human transcriptomic and epigenomic datasets to study the disease mechanism of NCMD. We highlight the value of computational approaches for the evaluation of candidate non-coding variants and discuss the importance of taking spatio-temporal context into account in these analyses. Furthermore, we report a common peripheral retinal finding challenging the notion that NCMD is a disorder strictly confined to the macula.

\section{Acknowledgements}

We acknowledge the following sources of support and funding: Christopher Green Doctoral Fellowship (DJG), UK National Institute for Health Research (NIHR) Clinical Lecturer Award (CL-2017-06-001, PIS), Health Education England Postdoctoral Research Fellowship (JME), Wellcome Trust Sir Henry Wellcome Fellowship (103986/Z/14/Z, CSM). 
medRxiv preprint doi: https://doi.org/10.1101/2021.03.05.21252975; this version posted March 8, 2021. The copyright holder for this preprint (which was not certified by peer review) is the author/funder, who has granted medRxiv a license to display the preprint in perpetuity.

It is made available under a CC-BY-NC-ND 4.0 International license .

\section{REFERENCES}

1. Small KW, Udar N, Ph D, et al. North Carolina Macular Dystrophy is caused by dysregulation of the retinal transcription factor PRDM13. 2016;123(1):319-335. doi:10.1016/j.ophtha.2015.10.006.North

2. Silva RS, Arno G, Cipriani V, et al. Unique noncoding variants upstream of PRDM13 are associated with a spectrum of developmental retinal dystrophies including progressive bifocal chorioretinal atrophy. Hum Mutat. 2019;40(5):578-587. doi:10.1002/humu.23715

3. Small KW, Tran EM, Small L, Rao RC, Shaya F. Multimodal Imaging and Functional Testing in a North Carolina Macular Disease Family: Toxoplasmosis, Fovea Plana, and Torpedo Maculopathy Are Phenocopies. Ophthalmol Retin. 2019;3(7):607-614. doi:10.1016/j.oret.2019.03.002

4. Small KW, Vincent AL, Knapper CL, Shaya FS. Congenital toxoplasmosis as one phenocopy of North Carolina Macular Dystrophy (NCMD/MCDR1). Am J Ophthalmol Case Reports. 2019;15:100521. doi:10.1016/j.ajoc.2019.100521

5. Small KW. North Carolina macular dystrophy: clinical features, genealogy, and genetic linkage analysis. Trans Am Ophthalmol Soc. 1998;96:925-961.

6. Small KW. North Carolina Macular Dystrophy, Revisited. Ophthalmology. 1989;96(12):1747-1754. doi:10.1016/S0161-6420(89)32655-8

7. Lefler WH, Wadsworth JAC, Sidbury JB. Hereditary macular degeneration and amino-aciduria. Am J Ophthalmol. 1971;71(1 PART 2):224-230. doi:10.1016/0002-9394(71)90394-1

8. Frank HR, Landers MB, Williams RJ, Sidbury JB. A new dominant progressive foveal dystrophy. Am J Ophthalmol. 1974;78(6):903-916. doi:10.1016/00029394(74)90800-9 
9. Namburi P, Khateb S, Meyer S, et al. A unique PRDM13-associated variant in a Georgian Jewish family with probable North Carolina macular dystrophy and the possible contribution of a unique CFH variant. Mol Vis. 2020;26:299-310.

10. Rosenberg T, Roos B, Johnsen T, et al. Clinical and genetic characterization of a Danish family with North Carolina macular dystrophy. Mol Vis.

2010;16:2659-2668.

11. Reichel MB, Kelsell RE, Fan J, et al. Phenotype of a British North Carolina macular dystrophy family linked to chromosome $6 \mathrm{q} . \mathrm{Br} J$ Ophthalmol. 1998;82(10):1162-1168. doi:10.1136/bjo.82.10.1162

12. Kiernan DF, Shah RJ, Hariprasad SM, et al. Thirty-Year follow-up of an African American family with macular dystrophy of the retina, locus 1 (North Carolina macular dystrophy). Ophthalmology. 2011;118(7):1435-1443.

13. Small KW, Garcia CA, Gallardo G, Udar N, Yelchits S. North Carolina macular dystrophy (MCDR1) in Texas. Retina. 1998;18(5):448-452.

14. Ellingford JM, Sergouniotis PI, Jenkins E, Black GC. Genome sequencing identifies a non-coding variant in the MCDR1 locus as a cause of macular dystrophy. Clin Experiment Ophthalmol. 2017;45(3):297-299. doi:10.1111/ceo.12825

15. Manes G, Joly W, Guignard T, et al. A novel duplication of PRMD13 causes North Carolina macular dystrophy: Overexpression of PRDM13 orthologue in drosophila eye reproduces the human phenotype. Hum Mol Genet. 2017;26(22):4367-4374. doi:10.1093/hmg/ddx322

16. Watanabe S, Sanuki R, Sugita $Y$, et al. Prdm13 regulates subtype specification of retinal amacrine interneurons and modulates visual sensitivity. J Neurosci. 2015;35(20):8004-8020. doi:10.1523/JNEUROSCI.0089-15.2015 
medRxiv preprint doi: https://doi.org/10.1101/2021.03.05.21252975; this version posted March 8, 2021. The copyright holder for this preprint (which was not certified by peer review) is the author/funder, who has granted medRxiv a license to display the preprint in perpetuity.

It is made available under a CC-BY-NC-ND 4.0 International license .

17. Bessodes N, Parain K, Bronchain O, Bellefroid EJ, Perron M. Prdm13 forms a feedback loop with Ptf1a and is required for glycinergic amacrine cell genesis in the Xenopus Retina. Neural Dev. 2017;12(1):1-15. doi:10.1186/s13064-0170093-2

18. Bhatia S, Bengani H, Fish M, et al. Disruption of autoregulatory feedback by a mutation in a remote, ultraconserved PAX6 enhancer causes aniridia. Am J Hum Genet. 2013;93(6):1126-1134. doi:10.1016/j.ajhg.2013.10.028

19. Vandermeer JE, Ahituv N. Cis-Regulatory Mutations Are a Genetic Cause of Human Limb Malformations. Dev Dyn. 2011;240(5):920-930. doi:10.1002/dvdy.22535

20. Gasperini M, Tome JM, Shendure J. Towards a comprehensive catalogue of validated and target-linked human enhancers. Nat Rev Genet. 1981;40. doi:10.1038/s41576-019-0209-0

21. Abascal F, Acosta R, Addleman NJ, et al. Expanded encyclopaedias of DNA elements in the human and mouse genomes. Nature. 2020;583(7818):699710. doi:10.1038/s41586-020-2493-4

22. Domcke S, Hill AJ, Daza RM, et al. A human cell atlas of fetal chromatin accessibility. Science. 2020;370(6518). doi:10.1126/science.aba7612

23. Cao J, O'Day DR, Pliner HA, et al. A human cell atlas of fetal gene expression. Science. 2020;370(808). doi:10.1126/science.aba7612

24. Fulco CP, Nasser J, Jones TR, et al. Activity-by-contact model of enhancerpromoter regulation from thousands of CRISPR perturbations. Nat Genet. 2019;51(12):1664-1669. doi:10.1038/s41588-019-0538-0

25. Abascal F, Acosta R, Addleman NJ, et al. Perspectives on ENCODE. Nature. 2020;583(7818):693-698. doi:10.1038/s41586-020-2449-8 
medRxiv preprint doi: https://doi.org/10.1101/2021.03.05.21252975; this version posted March 8, 2021. The copyright holder for this preprint (which was not certified by peer review) is the author/funder, who has granted medRxiv a license to display the preprint in perpetuity.

It is made available under a CC-BY-NC-ND 4.0 International license .

26. Dixon JR, Jung I, Selvaraj S, et al. Chromatin architecture reorganization during stem cell differentiation. Nature. 2015;518(7539):331-336.

doi:10.1038/nature14222

27. Cherry TJ, Yang MG, Harmin DA, et al. Epigenomic Profiling and SingleNucleus-RNA-Seq Reveal Cis-Regulatory Elements in Human Retina, Macula and RPE and Non-Coding Genetic Variation. 2018.

28. de Bruijn SE, Fiorentino A, Ottaviani D, et al. Structural Variants Create New Topological-Associated Domains and Ectopic Retinal Enhancer-Gene Contact in Dominant Retinitis Pigmentosa. Am J Hum Genet. 2020;107(5):802-814. doi:10.1016/j.ajhg.2020.09.002

29. Karczewski KJ, Francioli LC, Tiao G, et al. Variation across 141,456 human exomes and genomes reveals the spectrum of loss-of-function intolerance across human protein-coding genes. bioRxiv. 2019:531210. doi:10.1101/531210

30. Zachary A, Torres R, Taliun SAG, et al. Sequencing of 53,831 diverse genomes from the NHLBI TOPMed Program. 2019:1-46.

31. Rentzsch P, Witten D, Cooper GM, Shendure J, Kircher M. CADD: Predicting the deleteriousness of variants throughout the human genome. Nucleic Acids Res. 2019;47(D1):D886-D894. doi:10.1093/nar/gky1016

32. Zhang $\mathrm{S}, \mathrm{He} \mathrm{Y}$, Liu $\mathrm{H}$, et al. regBase: whole genome base-wise aggregation and functional prediction for human non-coding regulatory variants. Nucleic Acids Res. 2019;47(21):e134. doi:10.1093/nar/gkz774

33. Cooper GM, Stone EA, Asimenos G, Green ED, Batzoglou S, Sidow A. Distribution and intensity of constraint in mammalian genomic sequence. Genome Res. 2005;15(7):901-913. doi:10.1101/gr.3577405 
medRxiv preprint doi: https://doi.org/10.1101/2021.03.05.21252975; this version posted March 8, 2021. The copyright holder for this preprint (which was not certified by peer review) is the author/funder, who has granted medRxiv a license to display the preprint in perpetuity.

It is made available under a CC-BY-NC-ND 4.0 International license .

34. Kent WJ, Sugnet CW, Furey TS, et al. The Human Genome Browser at UCSC.

Genome Res. 2002;12(6):996-1006. doi:10.1101/gr.229102

35. Genotype T, Expression T. The GTEx Consortium atlas of genetic regulatory effects across human tissues The Genotype Tissue Expression Consortium. 2019. doi:10.1101/787903

36. Ratnapriya R, Sosina OA, Starostik MR, et al. Retinal transcriptome and eQTL analyses identify genes associated with age-related macular degeneration. Nat Genet. 2019;51(4):606-610. doi:10.1038/s41588-019-0351-9

37. Chen S, Zhou Y, Chen Y, Gu J. Fastp: An ultra-fast all-in-one FASTQ preprocessor. Bioinformatics. 2018;34(17):i884-i890.

doi:10.1093/bioinformatics/bty560

38. Langmead B, Salzberg SL. Fast gapped-read alignment with Bowtie 2. Nat Methods. 2012;9(4):357-359. doi:10.1038/nmeth.1923

39. Li H, Handsaker B, Wysoker A, et al. The Sequence Alignment/Map format and SAMtools. Bioinformatics. 2009;25(16):2078-2079. doi:10.1093/bioinformatics/btp352

40. Gaspar JM. Improved peak-calling with MACS2. bioRxiv. 2018:1-16. doi:10.1101/496521

41. Swamy V, McGaughey D. Eye in a Disk: eyelntegration Human Pan-Eye and Body Transcriptome Database Version 1.0. Investig Opthalmology Vis Sci. 2019;60(8):3236. doi:10.1167/iovs.19-27106

42. Evans E. Salmon: fast and bias-aware quantification of transcript expression using dual-phase inference. Midwives Chron. 1972;86(11):118-119. doi:10.1038/nmeth.4197.Salmon

43. Wells A, Heckerman D, Torkamani A, et al. Ranking of non-coding pathogenic 
medRxiv preprint doi: https://doi.org/10.1101/2021.03.05.21252975; this version posted March 8, 2021. The copyright holder for this preprint (which was not certified by peer review) is the author/funder, who has granted medRxiv a license to display the preprint in perpetuity. It is made available under a CC-BY-NC-ND 4.0 International license .

variants and putative essential regions of the human genome. Nat Commun. 2019;10(1). doi:10.1038/s41467-019-13212-3

44. Hume MA, Barrera LA, Gisselbrecht SS, Bulyk ML. UniPROBE, update 2015: New tools and content for the online database of protein-binding microarray data on protein-DNA interactions. Nucleic Acids Res. 2015;43(D1):D117-D122. doi:10.1093/nar/gku1045

45. Voo I, Glasgow BJ, Flannery J, Udar N, Small KW. North Carolina macular dystrophy: Clinicopathologic correlation. Am J Ophthalmol. 2001;132(6):933935. doi:10.1016/S0002-9394(01)01184-9

46. Bakall B, Bryan JS, Stone EM, Small KW. Choroidal Neovascularization in North Carolina Macular Dystrophy Responsive To Anti-Vascular Endothelial Growth Factor Therapy. Retin Cases Brief Rep. 2018;Publish Ah. doi:10.1097/icb.0000000000000838

47. Rhee DY, Reichel E, Rogers A, Strominger M. Subfoveal choroidal neovascularization in a 3-year-old child with North Carolina macular dystrophy. J AAPOS. 2007;11(6):614-615. doi:10.1016/j.jaapos.2007.06.010

48. Pauleikhoff D, Sauer CG, Muller CR, Radermacher M, Merz A, Weber BHF. Clinical and genetic evidence for autosomal dominant North Carolina macular dystrophy in a German family. Am J Ophthalmol. 1997;124(3):412-415. doi:10.1016/S0002-9394(14)70842-6

49. Small KW, Killian J, McLean WC. North Carolina's dominant progressive foveal dystrophy: How progressive is it? Br J Ophthalmol. 1991;75(7):401-406. doi:10.1136/bjo.75.7.401

50. Hoshino A, Ratnapriya R, Brooks MJ, et al. Molecular Anatomy of the Developing Human Retina. Dev Cell. 2017;43(6):763-779.e4. 
medRxiv preprint doi: https://doi.org/10.1101/2021.03.05.21252975; this version posted March 8, 2021. The copyright holder for this preprint (which was not certified by peer review) is the author/funder, who has granted medRxiv a license to display the preprint in perpetuity.

It is made available under a CC-BY-NC-ND 4.0 International license.

doi:10.1016/j.devcel.2017.10.029

51. Mellough CB, Bauer R, Collin J, et al. An integrated transcriptional analysis of the developing human retina. Dev. 2019;146(2). doi:10.1242/dev.169474 
medRxiv preprint doi: https://doi.org/10.1101/2021.03.05.21252975; this version posted March 8, 2021. The copyright holder for this preprint (which was not certified by peer review) is the author/funder, who has granted medRxiv a license to display the preprint in perpetuity.

It is made available under a CC-BY-NC-ND 4.0 International license .

\section{FIGURE LEGENDS}

Figure 1. Pedigrees from three families segregating North Carolina macular dystrophy. Study participants are highlighted with asterisks. We note that findings from the two affected females from family 75898 are also discussed in ${ }^{14}$

Figure 2. Color fundus photography, fundus autofluorescence imaging and OCT from four individuals who have North Carolina macular dystrophy and are heterozygous for the chr6:100,040,987 variant (GRCh37/hg19).

[A] Macular findings in a 6-year-old child are shown. A macular coloboma-like excavation is seen; there is extensive subretinal fibrosis centrally with residual pockets of intraretinal fluid despite treatment with four intravitreal bevacizumab injections. Images of the affected mother and grandmother of this proband can be found in Ellingford et al. (2017). ${ }^{14}$

[B] Macular findings in a 36-year-old proband are shown. Subtle confluent yellowwhite specks are noted in the central macula. These are more visible on fundus autofluorescence imaging and correspond to hyperautofluorescent lesions. Only a subset of these changes were readily identifiable by OCT. No inner retinal layer abnormality could be detected.

[C,D] Macular findings in a 44-year-old proband and his 48-year-old brother are shown. Yellow-white foveal lesions, similar to those observed in the 36-year-old individual discussed above, are noted.

There was a high degree of interocular symmetry and only data from the right eye are shown. 
medRxiv preprint doi: https://doi.org/10.1101/2021.03.05.21252975; this version posted March 8, 2021. The copyright holder for this preprint

Figure 3. Digital widefield fundus imaging and fundus autofluorescence imaging in three probands who have North Carolina macular dystrophy and are heterozygous for the chr6:100,040,987 variant (GRCh37/hg19). Images from a 6-year-old [A], a 36year-old [B], and a 48-year-old [C] are shown. Yellow-white retinal spots, often very prominent and in radial alignment, are noted in the far temporal periphery of these three individuals. These spots correspond to hyperautofluorescent lesions on fundus autofluorescence imaging. White arrows are used to highlight some of these changes. Inferior lash artefact is noted in some images. There was a high degree of interocular symmetry and only data from the left eye are shown. It is worth noting that although there was significant phenotypic variability, widefield imaging revealed a maculopathy combined with peripheral drusen-like spots in all study participants.

Figure 4. Location of enhancer elements upstream of $P R D M 13$ in macula and retina as predicted by the Activity-by-Contact $(\mathrm{ABC})$ model. ${ }^{24} \mathrm{~A}$ putative enhancer encompasses the chr6:100,040,987G>C (GRCh37/hg19) variant, which was carried by the six study participants (green line in the variant row of the Figure). The enhancer encompassing this variant was not detected in retinal tissue and was only highlighted when a dataset from macular tissue was utilized. This enhancer encompasses another four variants that were previously identified in families with North Carolina macular dystrophy (NCMD): chr6:100,040,906G>T, chr6:100,040,974A>C, chr6:100,040,987G>C, and chr6:100,041,040C>T. A different candidate enhancer that was predicted to be functional in both macular and retinal tissue was altered by the chr6:100,046,783A>C variant. This change has been identified in a single family with two affected individuals, a mother and her child; while the mother had typical findings of NCMD, the child had broader retinal 
involvement in keeping with a related developmental disorder, progressive bifocal chorioretinal atrophy (PBCRA). ${ }^{2}$ Notably, an adjacent variant, chr6:100,046,804T>C (orange line in the variant row of the Figure), has been reported to cause PBCRA in six affected individuals from two families. ${ }^{2}$ The fact that the candidate enhancer encompassing these two PBCRA-implicated variants appears to have a role in both macular and retinal tissue may explain why individuals carrying these changes often develop a phenotype that is more severe than NCMD and is associated with generalized retinal dysfunction.

Figure 5. Expression levels of PRDM13 in different human tissues and cells. [A] gene expression of PRDM13 in human tissues from bulk RNA, taken from eyelntegration (https://eyeintegration.nei.nih.gov/: v1.05).

[B] gene expression of PRDM13 in cell populations from single-cell RNA-seq studies (https://plae.nei.nih.gov).

It is noteworthy that PRDM13 had very low expression levels $(<0.2$ TPM) in all extraocular tissues included in the Genotype-Tissue Expression (GTEx) project dataset. ${ }^{35}$ TPM, transcripts per million. CPM, counts per million. RPE, retinal pigment epithelium. 
medRxiv preprint doi: https://doi.org/10.1101/2021.03.05.21252975; this version posted March 8, 2021. The copyright holder for this preprint (which was not certified by peer review) is the author/funder, who has granted medRxiv a license to display the preprint in perpetuity.

It is made available under a CC-BY-NC-ND 4.0 International license .

Table 1. Clinical characteristics of individuals carrying the chr6:100,040,987G>C (GRCh37/hg19) change in heterozygous state

\begin{tabular}{|c|c|c|c|c|}
\hline patient & gender & $\begin{array}{l}\text { age } \\
\text { (at presentation; } \\
\text { age at last } \\
\text { examination) }\end{array}$ & $\begin{array}{l}\text { LogMAR vision } \\
\text { at last } \\
\text { examination } \\
\text { (right; left) }\end{array}$ & $\begin{array}{l}\text { main fundoscopic } \\
\text { findings }\end{array}$ \\
\hline 75898.1 & male & $3 ; 7$ & $0.5 ; 1.6$ & $\begin{array}{l}\text { coloboma-like macular } \\
\text { lesions; subfoveal scarring } \\
\text { and fluid due to } \\
\text { neovascularization; subtle } \\
\text { peripheral white spots }\end{array}$ \\
\hline 75898.2 & female & $4 ; 36$ & $0.5 ; 0.5$ & $\begin{array}{l}\text { coloboma-like macular } \\
\text { lesions with associated } \\
\text { macular white spots and a } \\
\text { degree of foveal sparing; } \\
\text { peripheral white spots }\end{array}$ \\
\hline 75898.3 & female & $4 ; 58$ & $1.5 ; 1.5$ & $\begin{array}{l}\text { coloboma-like macular } \\
\text { lesions with associated } \\
\text { macular white spots; } \\
\text { peripheral white spots }\end{array}$ \\
\hline 123660.1 & female & $35 ; 37$ & $0.0 ; 0.0$ & $\begin{array}{l}\text { macular and peripheral } \\
\text { white spots }\end{array}$ \\
\hline 89794.1 & male & $44 ; 50$ & $0.0 ; 0.0$ & $\begin{array}{l}\text { macular and peripheral } \\
\text { white spots }\end{array}$ \\
\hline 89794.2 & male & $46 ; 52$ & $0.0 ; 0.0$ & $\begin{array}{l}\text { macular and peripheral } \\
\text { white spots }\end{array}$ \\
\hline \multicolumn{5}{|c|}{$\begin{array}{l}89794.1 \text { and } 89794.2 \text { are brothers; } 75898.2 \text { is the daughter of } 75898.3 \text { and mother of } \\
75898.1 \text {. The genetic and phenotypic findings in } 75898.2 \text { and } 75898.3 \text { are also discussed in } \\
\text { 14 }\end{array}$} \\
\hline
\end{tabular}


Table 2. Single nucleotide variants in chromosome 6 associated with North Carolina macular dystrophy

\begin{tabular}{|c|c|c|c|c|c|c|c|c|c|}
\hline Variant (GRCh37/hg19) & $\begin{array}{c}\text { Variant } \\
\text { (GRCh38/hg38) }\end{array}$ & $\begin{array}{l}\text { gnom } A D \\
\text { allele count }\end{array}$ & $\begin{array}{l}\text { TOPMed } \\
\text { allele count }\end{array}$ & $\begin{array}{l}\text { CADD- } \\
\text { Phred } \\
\text { score }\end{array}$ & $\begin{array}{l}\text { regBas } \\
\text { e score }\end{array}$ & $\begin{array}{c}\text { ncER } \\
\text { perce } \\
\text { ntile }\end{array}$ & $\begin{array}{l}\text { GERP } \\
\text { score }\end{array}$ & $\begin{array}{l}\text { number } \\
\text { of } \\
\text { families } \\
\text { (number } \\
\text { of } \\
\text { affected) }\end{array}$ & $\begin{array}{l}\text { refere } \\
\text { nce }\end{array}$ \\
\hline chr6:100,040,906G>T & chr6:99,593,030G>T & $0 / \sim 152,100$ & $0 / \sim 264,690$ & 1.672 & 19.8 & 81.33 & -0.01 & $6(65)$ & 1 \\
\hline chr6:100,040,974A>C & chr6:99,593,098A>C & $0 / \sim 152,100$ & $0 / \sim 264,690$ & 1.465 & 8.3 & 73.36 & -2.19 & $1(6)$ & 9 \\
\hline chr6:100,040,987G>C & chr6:99,593,111G>C & $1 / 152,188$ & $0 / \sim 264,690$ & 9.133 & 19.5 & 79.83 & 2.52 & $8(20)$ & $1,3,4,14$ \\
\hline chr6:100,041,040C>T & chr6:99,593,164C>T & $0 / \sim 151,800$ & $0 / \sim 264,690$ & 5.647 & 16.9 & 69.37 & 1.72 & $1(2)$ & 1 \\
\hline chr6:100,046,783A>C $C^{*}$ & chr6:99,598,907A>C & $0 / \sim 152,100$ & $0 / \sim 264,690$ & 2.528 & 5.7 & 15.60 & -2.44 & $1(1)$ & 2 \\
\hline
\end{tabular}

gnomAD, Genome Aggregation Database v3.1 dataset; GERP, Genomic Evolutionary Rate Profiling; TOPMed, NHLBI Trans-Omics for Precision Medicine variant database freeze 8; CADD, combined annotation dependent depletion; ncER, non-coding essential regulation.

The CADD score ranges from 1 to 99 ; a higher score indicates greater pathogenicity. Values $\geq 10$ are predicted to be the $10 \%$ most deleterious substitutions and $\square \geq \square 20$ in the $1 \%$ most deleterious.

The nCER scores are percentiles. The higher the percentile, the more likely that a region is vital in terms of regulation. There is no agreed cutoff for deleteriousness but the original report focused on assessing the predictive power of the higher percentiles $\left(95^{\text {th }}\right.$ and above). ${ }^{43}$

The regBase scores are Phred-like and calculated using the "PAT" model, which attempts to determine whether a variant is deleterious. The scores range from 1 to 99 ; a higher score indicates greater pathogenicity. ${ }^{32}$

The GERP scores represent position-specific evolutionary constraint. Positive values suggest evolutionarily constrained positions, with a cut-off of 2 providing high sensitivity. ${ }^{33}$

*this variant has also been associated with progressive bifocal chorioretinal atrophy (PBCRA). Notably, a nearby variant, chr6:100,046,804T>C (GRCh37/hg19), has been found to cause PBCRA in six affected individuals from two families (see also Figure 4). ${ }^{2}$ 
medRxiv preprint doi: https://doi.org/10.1101/2021.03.05.21252975; this version posted March 8, 2021. The copyright holder for this preprint (which was not certified by peer review) is the author/funder, who has granted medRxiv a license to display the preprint in perpetuity.

\section{It is made available under a CC-BY-NC-ND 4.0 International license .}

Family 75898

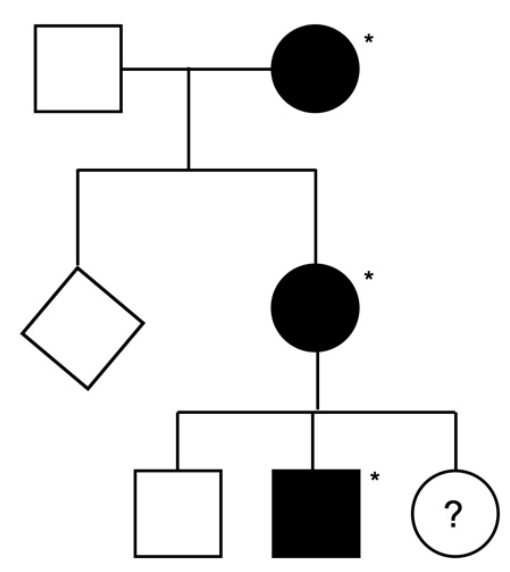

Family 123660

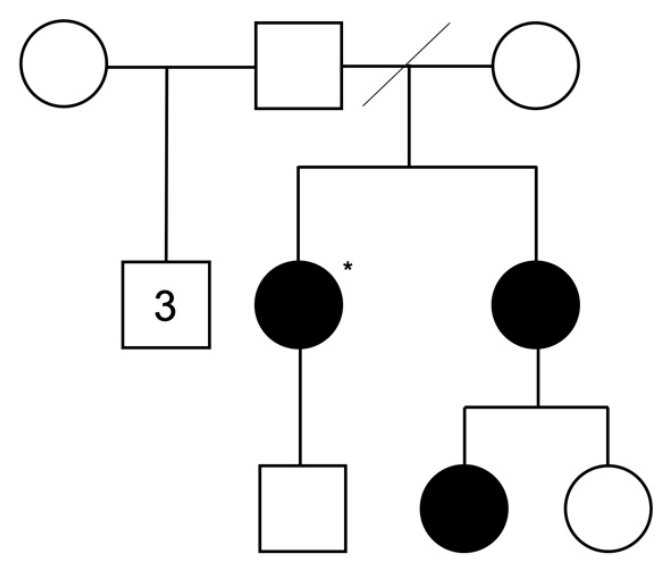

Family 89794

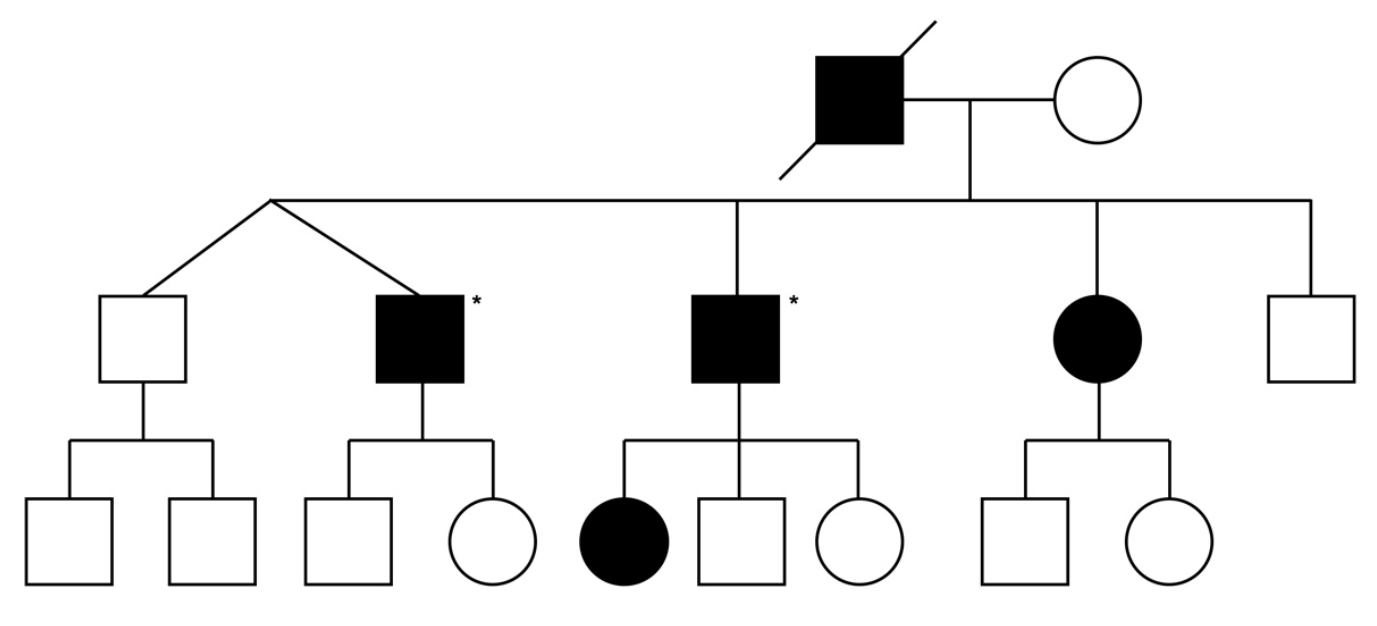

3 Figure 1. 
medRxiv preprint doi: https://doi.org/10.1101/2021.03.05.21252975; this version posted March 8, 2021. The copyright holder for this preprint (which was not certified by peer review) is the author/funder, who has granted medRxiv a license to display the preprint in perpetuity.

It is made available under a CC-BY-NC-ND 4.0 International license .

5

6

7

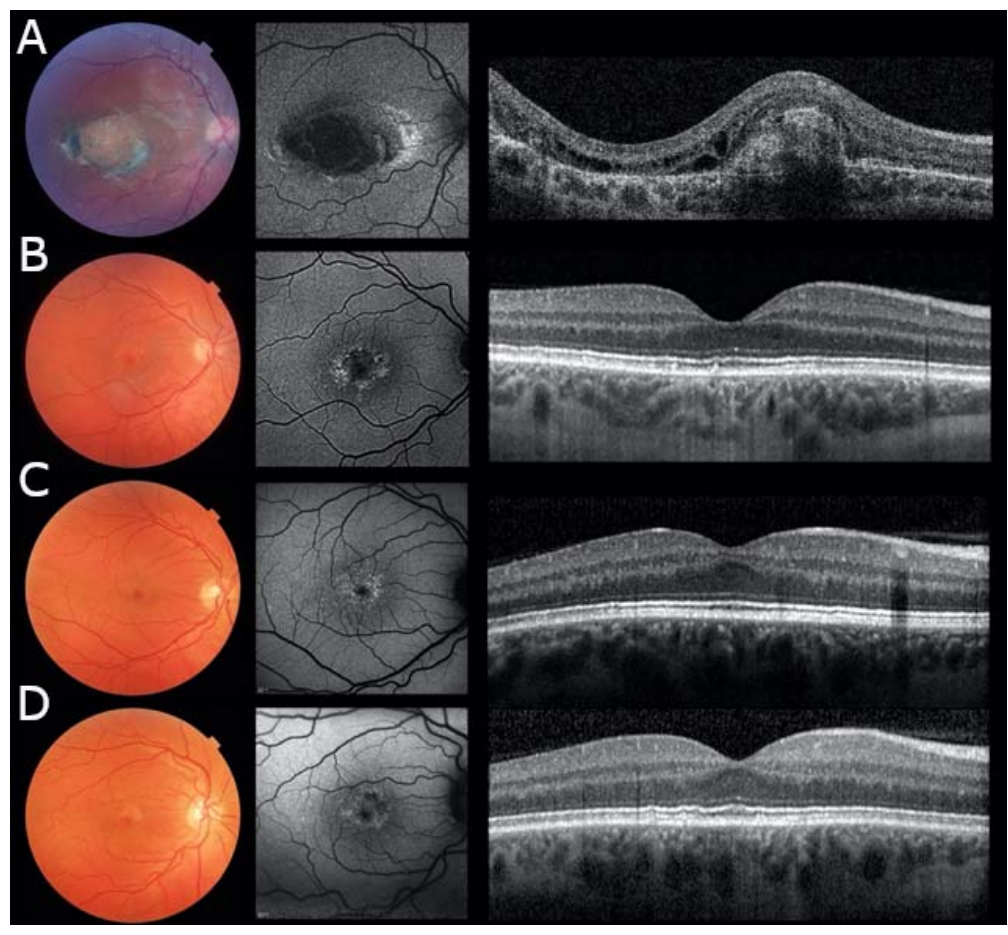

$8 \quad$ Figure 2. 
medRxiv preprint doi: https://doi.org/10.1101/2021.03.05.21252975; this version posted March 8, 2021. The copyright holder for this preprint (which was not certified by peer review) is the author/funder, who has granted medRxiv a license to display the preprint in perpetuity.

It is made available under a CC-BY-NC-ND 4.0 International license .

10

11

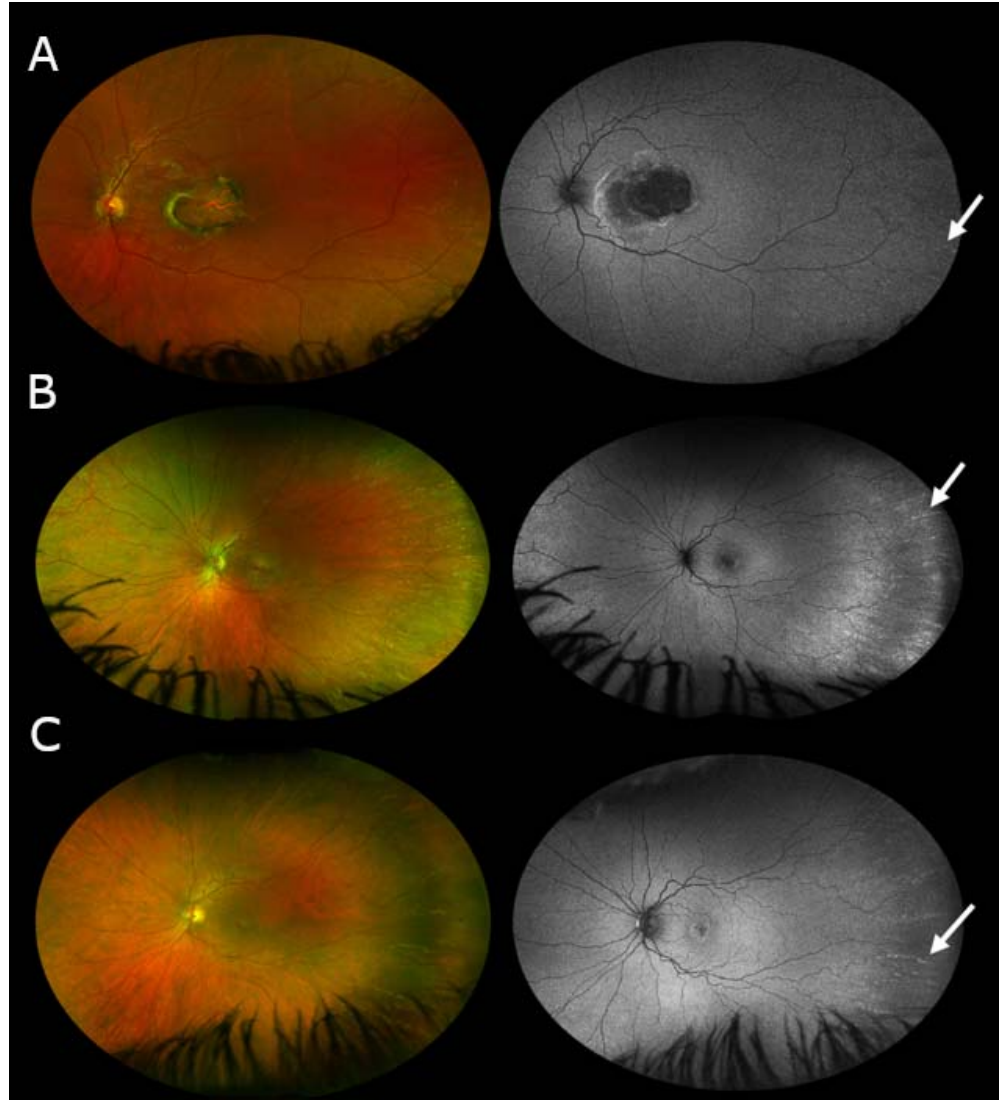

12 Figure 


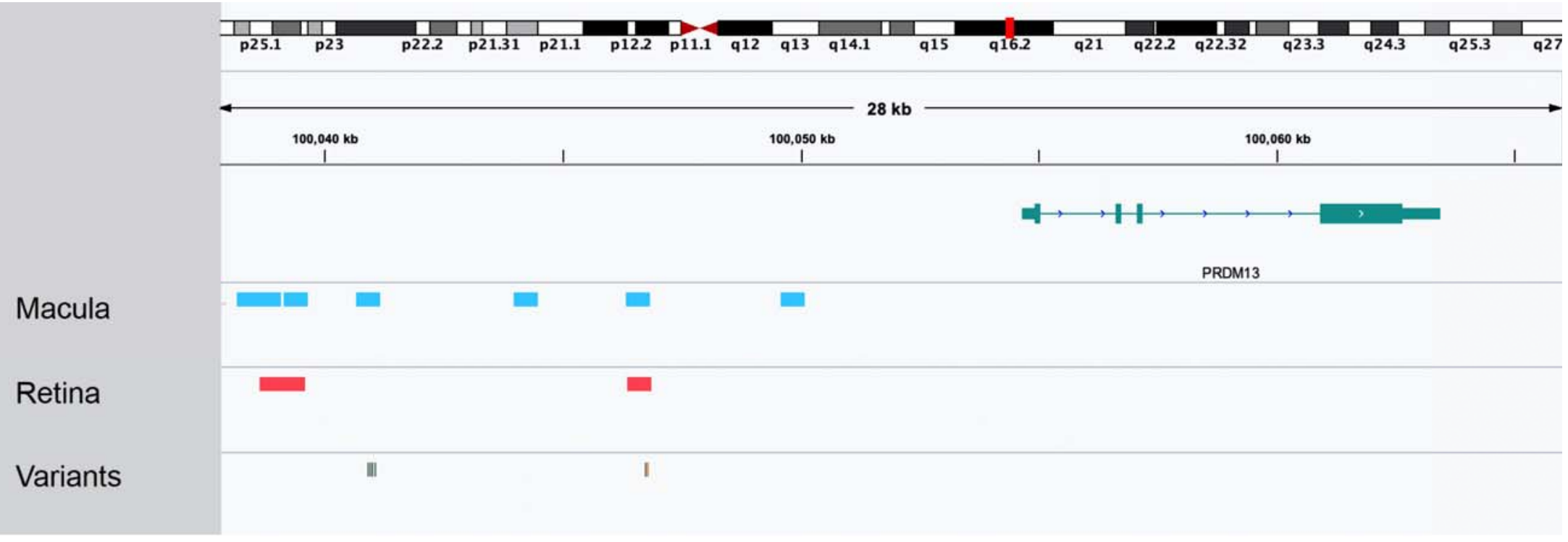

Figure 4. 
medRxiv preprint doi: https://doi.org/10.1101/2021.03.05.21252975; this version posted March 8, 2021. The copyright holder for this preprint (which was not certified by peer review) is the author/funder, who has granted medRxiv a license to display the preprint in perpetuity.

It is made available under a CC-BY-NC-ND 4.0 International license .

17

A RPE - Fetal Tissue

RPE - Stem Cell Line

RPE - Adult Tissue

Retinal Ganglion Cell Stem Cell

Retina - Adult Tissue

Retina - 3D Organoid Stem Cell

Macula - Adult Tissue

Retina - Fetal Tissue

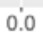

2.5

5.0

7.5

PRDM13 expression in log2(TPM+1)

B Retinal Astrocytes

Bipolar Cells

1

I

Retinal Precursor Cells

】

Retinal Microvascular Endothelial Cells

Retinal Pericytes

1

Photoreceptor Precursors

Neurogenic Cells

Horizontal Cells

Amacrine Cells

Amacrine/Horizontal Cell Precursors

I

$19 \quad$ Figure 5. 